\title{
CYP2B6*18 is associated with nevirpine hypersensitivity independently of HLA-C*04:01 in a Malawian HIV population
}

\author{
Daniel Carr ${ }^{1 *}$, Mas Chaponda ${ }^{2}$, Elena Cornejo Castro ${ }^{2}$, Andrea Jorgensen ${ }^{3}$, Saye Khoo ${ }^{4}$, Munir Pirmohamed ${ }^{4}$ \\ From 6th Drug Hypersensitivity Meeting (DHM 6) \\ Bern, Switzerland. 9-12 April 2014
}

Nevirapine (NVP), a non-nucleoside reverse transcriptase inhibitor (NNRTI) used in human immunodeficiency virus (HIV) treatment can cause hypersensitivity reactions in $6-10 \%$ of patients, which in the most serious cases (1.3\%) can manifest as Stevens-Johnson Syndrome (SJS) or Toxic Epidermal Necrolysis (TEN). A total of 209 patients with NVP hypersensitivity (57 from a prospective cohort and 152 clinic patients) were compared with 463 control patients on NVP without any hypersensitivity. The case group included 70 patients with serious blistering reactions (SJS or TEN). All individuals were genotyped for 2 SNPs in the CYP2B6 gene (c.516G>T [CYP2B6*9] and c.983T $>$ C [CYP2B6*18]) using the TaqMan real-time genotyping platform. A replication cohort of 29 controls and 31 nevirapine hypersensitive patients, including 8 SJS/TEN cases, was subsequently typed. An association between the CYP2B6*18 polymorphism and NVP-induced SJS/TEN was observed $(\mathrm{p}=0.013)$. In the SJS/TEN group, $30 \%$ of individuals possessed at least one "18 allele vs. $16 \%$ in the tolerant group ( $\mathrm{p}=0.006$; OR (95\% CI) 2.24(1.27-3.94)). This association was also borderline significant in the replication cohort $(\mathrm{p}=0.075)$. Combined analysis resulted in an odds ratio of 2.52 (95\% CI 1.48-4.20; $\mathrm{p}=0.0005)$ for the association of SJS/TEN with CYP2B6*18. This association was not observed for other hypersensitivity phenotypes. Data show a putative association between the CYP2B6*18 polymorphism and nevirapine-induced SJS/ TEN. CYP2B6*18 has a frequency of around $5-10 \%$ in African populations but is not observed in Caucasians, and this may therefore represent an ethnicity-specific predisposing factor.

\section{Authors' details}

${ }^{1}$ University of Liverpool, UK. ${ }^{2}$ University of Liverpool, Molecular and Clinical Pharmacology, UK. ${ }^{3}$ University of Liverpool, Biostatistics, UK. ${ }^{4}$ University of Liverpool, Molecular and Clinical Pharamcology, UK.

Published: 18 July 2014

doi:10.1186/2045-7022-4-S3-P126

Cite this article as: Carr et al:: CYP2B6*18 is associated with nevirpine hypersensitivity independently of HLA-C*04:01 in a Malawian HIV population. Clinical and Translational Allergy 2014 4(Suppl 3):P126.
Submit your next manuscript to BioMed Central and take full advantage of:

- Convenient online submission

- Thorough peer review

- No space constraints or color figure charges

- Immediate publication on acceptance

- Inclusion in PubMed, CAS, Scopus and Google Scholar

- Research which is freely available for redistribution
() Biomed Central
C Biomed Central

(c) 2014 Carr et al; licensee BioMed Central Ltd. This is an Open Access article distributed under the terms of the Creative Commons Attribution License (http://creativecommons.org/licenses/by/4.0), which permits unrestricted use, distribution, and reproduction in any medium, provided the original work is properly cited. The Creative Commons Public Domain Dedication waiver (http:// creativecommons.org/publicdomain/zero/1.0/) applies to the data made available in this article, unless otherwise stated. 